\title{
Algumas reflexões sobre Butler e a(s) melancolia(s) ${ }^{1}$
}

Cassiana L. Stephan ${ }^{2}$

\section{Introdução}

$\mathrm{B}_{\mathrm{o}}$ a noite a todas, a todos e a todes! Em primeiro lugar, eu agradeço imensamente à professora Marlene Tamanini e a Henrique Quagliato pela oportunidade de troca neste evento sobre os 30 anos de Problemas de Gênero. ${ }^{3}$ Agradeço também à professora Maria Rita pela presença. Gostaria de dizer que sempre fico muito emocionada quando estou ao seu lado, professora Rita, pois foi você quem me apresentou ao pensamento de Michel Foucault e é em sua postura ética e política que me espelho e me inspiro na construção da minha carreira acadêmica.

Bom, como eu sou da área da Filosofia, o meu trabalho pode soar um tanto quanto abstrato, embora eu constantemente busque materializar os conceitos que manipulo. Eu tentarei ser o mais clara possível aqui, mas se vocês tiverem alguma dúvida conceitual, por favor, não deixem de me perguntar.

Sei que o pensamento da Butler possui diferentes aplicações práticas e que se trata, portanto, de um pensamento com uma potência política incomensurável. A dimensão prática do pensamento butleriano me toca no que diz respeito à compreensão

\footnotetext{
'Esta conferência se baseia no artigo "Notas sobre o amor e a melancolia: da estrutura à resistência", publicado em agosto de 2020 na Revista Estudos Feministas: <https://periodicos.ufsc.br/index.php/ref/issue/view/3090>. Ademais, as discussões entretidas nesta fala também podem ser encontradas no terceiro capítulo de minha tese de doutorado, intitulada "Amor pelo avesso: de Afrodite a Medusa. Estética da existência entre antigos e contemporâneos" (Prêmio Filósofas de Destaque Acadêmico 2020 pela Rede Brasileira de Mulheres Filósofas). Por fim, vale ressaltar que as notas de rodapé não foram apresentadas na ocasião da conferência, mas as disponibilizo aqui para que as críticas de Butler em relação à psicanálise possam ser contextualizadas e eventualmente aprofundadas.

2 Doutora em Filosofia. Universidade Federal do Paraná (Brasil). Email: cassianastephan@yahoo.com.br.

3 Texto decorrente de fala ministrada no dia 17 de dezembro de 2020. Esta comunicação e o debate realizado por Maria Rita de Assis César (DTPEN-UFPR) podem ser acessados na íntegra através da página do Núcleo de Estudos de Gênero no Facebook. Disponível em: $<$ https://www.facebook.com/nucleodeestudosdegeneroufpr/videos/116o752210988215>. Acesso em $17 \mathrm{de}$ abril de 2021.
} 
da intimidade - intimidade que não é tão íntima assim, já que sempre está exposta às regulações normativas do Outro, o qual psiquicamente simboliza os diferentes mecanismos de poder-saber que operam na civilização. Este Outro ganha diferentes figurações no decorrer da história, ora ele é Deus, ora Razão, ora Falo. Ele também pode surgir no contexto da topografia interna dos sujeitos como uma mistura destas diferentes figurações, ou seja, como um Deus fálico, como um logos divino, como um logos divino e fálico, e assim por diante.

A meu ver, quando Butler se articula criticamente à psicanálise, ela vai além de Foucault, na medida em que redimensiona a problemática ético-política do cuidado de si e da estética da existência, permitindo-nos perceber que a vida psíquica dos poderes e dos saberes deve ser levada em consideração no que diz respeito à estilização de nossas próprias existências e à intervenção ético-política no mundo.

Então, hoje, levando em consideração as análises desenvolvidas por Butler em Problemas de Gênero (1990), mas também n'A vida psíquica do poder (1997), pretendo apresentar a vocês algumas reflexões sobre a melancolia. Também mobilizarei as análises de Foucault sobre a estética da existência e o cuidado de si na construção de meus argumentos com o intuito de lhes mostrar de que modo eu entrecruzo estes dois autores em minhas pesquisas. Foucault não aparecerá exaustivamente, mas apenas em alguns momentos.

Antes de efetivamente começar minha comunicação, gostaria de ressaltar que a noção de melancolia vem sendo retrabalhada por Butler e que em seu último livro, a saber, The force of non-violence, a ambivalência melancólica reaparece com mais clareza, sendo recontextualizada para além das questões de gênero. De modo geral, em The force of non-violence, Butler explica que existem duas maneiras pelas quais a melancolia pode ser vivenciada no contexto da constituição psíquica e social do si: podemos nos identificar ao Outro, entendido aqui como o horizonte de normatividade no qual o si está implicado cultural e historicamente, de modo a sacrificarmos nossa peculiaridade distintiva; contudo, também podemos nos des-identificar deste Outro em virtude de nós mesmas, isto é, sacrificá-lo em nome de nossa potência criativa. Segundo Butler, a melancolia é composta destas duas tendências opostas - cito Butler: 
[...] a primeira tendência é a autocensura, que se torna a assinatura da atuação da "consciência"; a segunda é a "mania", que busca quebrar o elo com o objeto perdido, renunciando ativamente o objeto que se foi. As denúncias "maníacas" e energéticas do objeto, mas também a intensificação dos esforços do ego em romper o elo com o ideal ou com o objeto perdido, implicam o desejo de sobreviver à perda e não o desejo de ter a própria vida reivindicada pela perda em si mesma. A Mania é, por assim dizer, o protesto do organismo vivo contra a prospecção de sua destruição por um super-eu não verificado. [...] A força maníaca que busca derrubar o tirano corresponde, de certa forma, ao poder que o organismo [vivo] possui para quebrar os elos considerados como aqueles que sustentam a identificação. [...] A des-identificação se torna um modo de oposição aos poderes de autodestruição, um modo de assegurar a vida do organismo em si mesmo (BUTLER, 2020, p.167, minha tradução).

Levando, pois, em consideração essas duas tendências opostas - a saber, a da autocensura identitária e a da mania que nos desidentifica - vou apresentar a vocês a diferença entre a melancolia oblativa ou estruturada, e a melancolia criativa ou desviante, no que se refere aos processos de identificação e desidentificação relativamente à matriz heterossexual. Então, vamos lá.

\section{A(s) melancolia(s)}

Para Butler, a melancolia corresponde a uma regulação psíquica do poder que constitui a identidade de gênero e que, de modo geral, determina a relação da subjetividade com as normas. Como explica Butler - eu a cito, “[...] a declaração da culpa, o juízo de inutilidade, os veredictos da realidade - são topograficamente representados como instrumentos psíquicos e instituições dentro de um panorama psíquico que por ser plausível depende de sua própria metaforicidade. O poder regulador se torna ‘interno’ somente através da produção melancólica da figura de um espaço interno. [...]” (BUTLER, 1997, p.197) Butler explica que a constituição melancólica do gênero consiste em um acontecimento que se estabelece por meio da intersecção entre a vida psíquica do sujeito e o significante que o demanda cultural e socialmente, o qual está vinculado na modernidade psicanalítica à simbolização fálica do Outro. A partir de Butler, talvez possamos afirmar que a melancolia possui duas disposições, a saber, uma estruturada e outra desviante. A melancolia estruturada ou oblativa seria regida pela lei patriarcal da psicanálise, que curaria os desvios da sexualidade por meio da aplicação dos códigos fálicos ao sujeito de desejo. Estas normas falocêntricas parecem conduzir à elaboração 
de uma reflexividade culposa. Diferentemente, a melancolia desviante ou criativa estaria vinculada à subversão da heteronormatividade, pois concerniria ao modo de subjetivação que se daria por meio da crítica em relação aos poderes e saberes do Falo. Com base nisso, as mazelas do amor moderno estariam relacionadas à normalização da melancolia oblativa, processo que alicerça a psiquê dos sujeitos na estrutura fálica, sistematizando seus laços sociais pela harmonização entre o interesse civil e a heteronormatividade do desejo. A melancolia estruturada funcionaria em razão da interdição dos prazeres que manifestam o alcance ético-político dos afetos atrelados à des-identificação em relação à heteronormatividade. Simultaneamente, a melancolia estruturada operaria em virtude da promulgação da moral e dos bons costumes, ou melhor, dos códigos que imputam a docilidade materno-matrimonial ao modo de ser mulher e o vigor paterno-patriarcal ao modo de ser homem.

Segundo Butler, a inteligibilidade dos amores modernos se deve à continuidade e à coerência entre a ficção atrelada à manifestação ontológica do sexo, à disposição natural do desejo e à normalidade psíquica e social do gênero. ${ }^{4}$ Nesse sentido, o desejo jogaria na modernidade um papel fundamental no que tange às condutas afetivas porque concerniria ao acontecimento psíquico que irrompe da articulação entre a verdade sobre a natureza e a verdade sobre a cultura do sujeito amoroso. Para Butler as leis da biologia dão origem à ficção de uma realidade binária que corresponde ao estatuto ontológico do macho e da fêmea, ao passo que as leis da psicanálise produzem, a partir destas duas possibilidades ôntico-genitais, a realidade cultural daquele que tem o falo e a realidade cultural daquela que é o falo..$^{5}$ Em outras palavras, o binarismo forjado, disseminado e

\footnotetext{
4 “Gêneros 'inteligíveis' são aqueles que em certo sentido instituem e mantêm relações de coerência e continuidade entre sexo, gênero, prática sexual e desejo. Em outras palavras, os espectros de descontinuidade e incoerência, eles mesmos pensáveis somente em relação às existentes normas de continuidade e coerência, são constantemente proibidos e produzidos pelas próprias leis que buscam estabelecer linhagens causais ou expressivas de conexão entre o sexo biológico, os gêneros culturalmente constituídos, e a 'expressão' ou o 'efeito' de ambos na manifestação do desejo sexual através da prática sexual. [...] A instituição de uma heterossexualidade compulsória e naturalizada requer e regula o gênero como uma relação binária, na qual o termo masculino é diferenciado do termo feminino e esta diferenciação é realizada através das práticas do desejo heterossexual." (BUTLER, 2002, p.23 e p.30, minha tradução).

5 "O falo é a função pivô, diria eu, que nos permite situar aquilo que dele se distingue, ou seja, $a$, e no pequeno $a$ enquanto pequeno $a$, a função geral do objeto de desejo. No coração da função pequeno $a$, permitindo agrupar os diferentes modos de objetos possíveis que intervêm na fantasia, existe o falo. Este é o objeto, como eu disse, que permite situar sua série, o ponto de origem, para frente e para trás. (LACAN, 2010, p.462).
} 
investido pelo discurso do positivismo científico é metonimicamente retomado pela imagem psicanalítica do Falo, a qual é elaborada através de - cito Butler - "uma linguagem estruturada pela lei patriarcal e pelos seus mecanismos de diferenciação.” (BUTLER, 2002, p.56, minha tradução) Dessa maneira parece que as distinções psicanalíticas acerca dos desejos masculinos e femininos advêm da mescla entre a fábula médico-científica do naturalismo binário e o mito filosófico-antropológico do patriarcado. ${ }^{6}$

A ciência explica o amor como uma sinapse que conecta as funções cerebrais às genitais, ou melhor, para a biologia e para a medicina o amor corresponde a uma necessidade fisiológica que garante a perpetuação da espécie humana. $O$ princípio teleológico da reprodução justifica o discurso científico que descreve e prescreve a simetrização da diferença entre o corpo do macho e o corpo da fêmea. Ademais, Butler mostra que a reprodução também é pressuposta, reiterada e racionalizada pela lei do patriarcado, já que os filhos homens manifestam a consolidação da ligação e da diferença entre os clãs patriarcais envolvidos em determinado intercurso social, enquanto as filhas mulheres viabilizariam tal comunicação. Mais especificamente, as mulheres serviriam ao casamento para facilitar a comutação identitária entre os homens que constituem diferentes linhagens paternais - cito Butler: "a noiva funciona como um termo relacional entre grupos de homens; ela não tem uma identidade e nem mesmo troca uma

\footnotetext{
${ }^{6}$ Butler, assim como Foucault, afirma que a verdade acerca da subjetividade e da realidade que a permeia consiste em uma ficção alicerçada pelo poder atinente à aplicação prática dos saberes ensejados e delimitados por determinado discurso: "[...] em que sentido isto é ficção? Foucault se refere a 'uma prática histórico-filosófica [na qual] se trata de fazer a própria história, de fabricar a história, como por ficção [de faire comme par fiction], nos termos em que ela estaria atravessada pela questão da relação entre as estruturas de racionalidade que articulam o discurso verdadeiro e os mecanismos de subjetivação que estão ligados a ele.' Há, dessa maneira, uma dimensão da metodologia (críticogenealógica) que parte da ficção, que desenha linhas ficcionais entre a racionalização e a dessubjetivação, entre o nexo saber-poder e a sua fragilidade ou limite." (BUTLER, 2001, p.15, minha tradução) De acordo com Butler, a repetição compulsória dos saberes fabulados faz com que o aspecto ficcional dos discursos seja obliterado ou disfarçado pela magnanimidade da lei, a qual apresenta a ficção histórico-filosófica como um código universal fundado em uma verdade absoluta. Em outras palavras, a reiteração acrítica dos discursos nos impede de vislumbrar a pluralidade das linguagens que coexistem nas distintas circunstâncias espaço-temporais e, sendo assim, de praticar a identidade como um repente criativo ou performático que não precisa se ater aos limites da razão universal. Para Butler, "o sujeito não é determinado pelas regras por meio das quais é gerado porque a significação não é um ato fundante, mas sim um processo regulatório de repetição que esconde a si mesmo e reforça as suas próprias regras precisamente através da produção de efeitos de substancialização." (BUTLER, 2002, p.185, minha tradução, grifo meu; cf. também a subseção 2.3.2 A ficção, do segundo capítulo da presente tese).
} 
identidade por outra. Ela reflete a identidade masculina precisamente por corresponder ao lugar de sua ausência.” (BUTLER, 2002, p.5o, minha tradução) No contexto do patriarcado, a maternidade e o matrimônio exprimem a condicionalidade das mulheres ao protagonismo político-social dos homens, pois a mãe e a noiva não constituem autarquicamente suas identidades femininas, mas correspondem a instrumentos manuseados pelos homens que buscam fortalecer a imagem pública de suas linhagens através da realização de estratégicas amizades masculinas. Segundo a lei do patriarcado, as mulheres concernem aos objetos que instituem a relação de reciprocidade entre os homens, a qual - cito Butler - "é a condição de uma relação radical de não-reciprocidade entre homens e mulheres e de uma relação, por assim dizer, de não-relação entre mulheres." (Ibidem, p.53, minha tradução) Logo, o patriarcado parece operar de maneira a distinguir entre o estatuto público da amizade e a dimensão privada do amor. Por um lado, a amizade condiz à relação horizontal entre os chefes de família; por outro lado, o amor reúne, numa única e mesma fórmula, (1) a diferenciação simétrica entre o corpo do homem e o corpo da mulher e (2) a instrumentalização hierárquica deste objeto feminino por aquele sujeito masculino, visto que a organização econômica do matrimônio se articula, sob a clave da misoginia, à dialética do senhor e do escravo. $\mathrm{O}$ amor pelas mulheres é vivenciado como a apropriação de um objeto matrimonial que assegura a reprodução e intermedeia a instituição de amizades masculinas, demasiado masculinas.

A partir disso Butler explica que a configuração psicanalítica do bom funcionamento do desejo subjetivo se atrela ao cenário biológico-patriarcal sobre o qual o amor moderno é performado. A aparência universal do discurso da psicanálise provém da mistura entre o saber médico-científico e o saber filosófico-antropológico, porém é interessante apontar que a eficácia prática da linguagem psicanalítica também depende da moralização do desejo, isto é, o caráter terapêutico da psicanálise residiria na delimitação da salubridade e da decência do desejo a ser liberado pelo sujeito amoroso. Conforme Butler, podemos afirmar que a parametrização psicanalítica do mundo interior se institui através da criação de uma estrutura de significação que deve ser mobilizada como o fundamento do desejo amoroso. (BUTLER, 2002, pp.56-57) Com base nisso, parece que este símbolo pré-ontológico da psicanálise precisaria arcar com a 
morte de Deus, ou melhor, precisaria desbancar, por meio da invenção de um símbolo tão inacessível quanto o divino, o discurso nietzschiano anunciado pelo homem louco cito Nietzsche: “'Procuro Deus! Procuro Deus!' [...] 'Para onde foi Deus?', gritou ele, ‘já lhes direi! Nós o matamos - vocês e eu. Somos todos assassinos!" (NIETZSCHE, 2012, Aforismo 125, p.137) Ora, parece que com a morte de Deus as identidades atreladas aos códigos universais baseados na transcendência divina foram subvertidas, ou seja, a morte de Deus abriria espaço para a experiência da morte de um si mesmo determinado pelos deveres e interdições legitimados pela codificação pastoral e inquisitória, ligada à simbologia cristã da divindade. A mortificação das identidades constituídas à imagem e semelhança de Deus conduziria à criação de uma anatomia profana que se multiplicaria pela incitação às práticas autárquicas e às reflexividades críticas. (FOUCAULT, 2001, no 339, p.1393) Estas, por sua vez, implicariam a sensação paradoxal de um prazer que não advém da supressão total da dor, mas do esforço vinculado à transformação ética de si. No contexto em que o Outro deixa de ser simbolizado pela figuração transcendental de Deus, a psicanálise parece emergir como a ciência que buscaria salvar os amantes desestruturados pela morte do divino. Parece que, em seu limiar patriarcal, a psicanálise se interessara pela cura da estrutura psíquica da consciência melancólica do homem dócil e da mulher viril, já que estes sujeitos teriam surgido no intervalo da morte de Deus e não teriam sentido a Sua falta, rendendo-se, num impulso criativo, à experiência dos amores lascivos e à constituição de identidades desviantes. Esta falta precisaria ser elaborada como culpa, ou seja, como luto pela morte do Outro. Para tanto, fez-se necessário transferir o amor que este sujeito sentia por Deus a um outro objeto que não o si mesmo aberto a transgressões possíveis. O amor-próprio do melancólico desviante deve ser curado pela introdução de um Outro capaz de ratificar e retificar as verdades divinas concernentes ao binarismo anatômico dos corpos de mulheres e homens. Assim, o Falo teria aparecido como o símbolo do objeto que restabeleceria a continuidade entre o sexo, o desejo e o gênero sob a luz da lei do patriarcado, de maneira a sedimentar o amor moderno na heteronormatividade. 7

\footnotetext{
${ }^{7}$ A substituição de Deus pelo Falo parece ser percebida por aquelas cujos desvios a psicanálise visa curar, ou seja, tal ratificação e retificação simbólica parece ser compreendida pela obsessiva que degrada a arquitetura patriarcal ao confrontar o narcisismo masculino através da subversão do desejo e da transgressão do prazer. Talvez seja por este motivo, por esta astúcia perceptiva, que irrompam em sua
} 
Conforme Butler, o Falo carrega o peso da tradição binária, patriarcal e moralizante difundida pela filosofia, pela antropologia, pela ciência e pela religião. Portanto, o Falo ainda corresponde a um símbolo inventado e aplicado por uma perspectiva heterossexual masculina que busca se absolutiza através da proibição da diferença atrelada à subversão e à transgressão dos amores femininos e dos amores gays - cito Butler: “[...] nós podemos entender esta conclusão [acerca da estruturação fálica do amor, que conduz à observação lacaniana do estatuto assexual da lésbica e do estatuto pervertido do gay] como sendo um resultado necessário que se segue de um ponto de vista observacional masculino e heterossexual, o qual concebe a sexualidade lésbica [por exemplo] como a recusa da sexualidade per se porque a sexualidade é presumida como heterossexual e porque o observador, aqui construído como o macho heterossexual, é claramente recusado.” (BUTLER, 2002, p.63, minha tradução) Talvez possamos afirmar que a novidade do símbolo fálico em relação ao Deus recém assassinado se vincule ao fato de que a psicanálise, diferentemente das doutrinas cristãs, não busca purificar o desejo por meio de atos confessionais que expurgariam os pecados da carne, mas sim elaborar o desejo subjetivo a partir da normalização da melancolia estruturada, a qual concerne a um estágio psíquico que garantiria a adequada liberação das pulsões amorosas, na medida em que, segundo Butler, a heterossexualidade resultaria da perda não elaborada da possibilidade do desejo homossexual. Como afirma Foucault, enquanto a fórmula do amor cristão - eu o cito - "coloca o acento sobre o desejo na tentativa de suprimi-lo" (FOUCAULT, 2001, nº 326, p.1219, minha tradução), por outro lado, a fórmula do amor moderno realça o desejo na tentativa de reiterar a heteronormatividade sob o viés da liberação, ou seja, podemos e devemos liberar o desejo, desde que ele seja heterossexual. Parece que a psicanálise salvaria o amor da luxúria ensejada pela morte de Deus ao patologizar a psiquê dos indivíduos que vivenciam a multiplicidade dos prazeres na recusa do Outro, ou melhor, na perda da normatividade do desejo que afirma a heterossexualidade e simultaneamente condena outras formas de amor. ${ }^{8} \mathrm{~A}$

psiquê "algumas fantasias sacrílegas nas quais a figura do Cristo, até mesmo o seu próprio falo, são pisoteados, de onde surge para a paciente uma aura erótica percebida e confessada." (LACAN, 2010, p.306).

${ }^{8}$ A psicanálise naturalizaria a psiquê do heterossexual que libera um desejo pudico, o qual, ao invés de incitar o prazer, causa a ansiosa nostalgia relativa à jouissance experenciada naquele passado, ainda porvir, vislumbrado pelo homem louco que suicidara o si mesmo constituído à imagem e semelhança de 
partir de Butler, talvez possamos afirmar que a liberação do desejo heterossexual dispensa os prazeres transgressivos quando interdita, a fim de garantir a salubridade dos sujeitos amorosos, outros tipos de desejo. Neste caso, os amantes direcionam seus olhares ao Falo e o incorporam sob a forma mascarada do ser ou sob a forma narcísica do $\operatorname{ter} .{ }^{9} \mathrm{O}$ sujeito que ama elabora a consciência de sua identidade de gênero na medida em que internaliza o Símbolo que rege o objeto do seu desejo. A salubridade mental dos amantes dependeria da incorporação do Falo, isto é, dependeria (1) da afirmação do amor reprodutivo e hierárquico entre pessoas simetricamente distintas no que tange à disposição anatômica de seus órgãos sexuais, e (2) da renúncia dos prazeres atrelados à transgressão gay ou feminina/feminista em relação ao desejo pudico, dado que - cito Butler, "a identidade heterossexual se conquista pela incorporação melancólica do amor que renuncia: o homem que insiste na coerência de sua heterossexualidade afirmará que nunca amou outro homem [...].” (BUTLER, 1997, p.139) A identidade heterossexual parece ser instituída através da fusão do si mesmo com o Falo, de tal modo que as mulheres se fundem aos homens e os homens se fundem a si mesmos, visto que a linguagem fálica imita a reciprocidade patriarcal entre os homens, a qual se constitui pela não reciprocidade entre homens e mulheres e pela relação de não-relação entre mulheres.

Assim, de acordo com esta nova simbologia, a disposição natural do desejo feminino estaria orientada àquilo que as mulheres não têm, ao passo que a disposição natural do desejo masculino estaria orientada à reapresentação daquilo que os homens têm. Isso significa que a feminilidade é elaborada pela incorporação de uma máscara fálica, ou seja, na matriz heterossexual o gênero feminino é instituído como um objeto

\footnotetext{
Deus. "Embora alguém possa argumentar que para Lacan a repressão cria o reprimido através da proibição e da lei patriarcal, este argumento não leva em consideração a prevalência da nostalgia para a perda completa da jouissance [...]. De fato, a perda poderia não ser entendida como uma perda, a menos que a própria irrecuperabilidade daquele prazer não tenha designado um passado que é barrado do presente pela lei proibitiva." (BUTLER, 2002, p.71, minha tradução).

9 Sobre a estruturação fálica do amor, Lacan explica o seguinte: "Se vocês lerem Abraham, vão encontrar esta expressão, Die Objekt-Partialliebe, o amor parcial do objeto. O que é o objeto desse amor, o objeto mais que exemplar, o único e verdadeiro objeto, ainda que outros possam se inscrever na mesma estrutura, é o falo. [...] O amor parcial do objeto, o que significa isso para Abraham? [...] É justamente o amor prestes a aceder ao objeto normal, o amor do outro sexo, o amor implicado nesse estágio capital, estruturante, estrutural, a que chamamos estágio fálico, é justamente o amor do outro [...]." (LACAN, 2010, p.461).
} 
que representa a subjetividade daquele que tem o falo. A feminilidade heterossexual é significada pela demanda da subjetividade masculina, já que a mulher é constituída como um sujeito de desejo quando objetificada em razão do falo que lhe falta. ${ }^{10}$ De acordo com a linguagem patriarcal da psicanálise, o olhar que a mulher possui sobre si mesma seria engendrado pelo olhar masculino do Outro, de tal modo que a mulher se conceberia como um objeto de desejo cujo destino corresponderia à confirmação da virilidade masculina por meio do matrimônio e da maternidade. Diferentemente, o olhar que o homem possui sobre si mesmo seria produzido por meio da perspectiva mascarada que o representa, ou melhor, pelo ponto de vista da mulher que reflete em seu olhar a imagem masculina daquele que a cobiça. ${ }^{11}$ Talvez possamos admitir que a constituição da consciência masculina é narcísica, pois o homem heterossexual só consegue - ou só deve - amar a mulher que carrega sobre si, em seu olhar mascarado, o espelho fálico. Como explica Butler - eu a cito:

\begin{abstract}
Diz-se que as mulheres são o Falo no sentido de que elas mantêm o poder de refletir ou de representar a "realidade" auto-fundamentadora do sujeito masculino; esse poder, se fosse abandonado, romperia com as ilusões fundamentais da posição do sujeito masculino. A fim de "ser" o Falo, aquilo que reflete e garante uma aparente posição do sujeito masculino, as mulheres devem se tornar, devem "ser" (no sentido de que elas devem agir "como se elas fossem") precisamente o que os homens não são e, nisso que muito lhes falta, elas devem estabelecer a função essencial dos homens (BUTLER, 2002, p.58, minha tradução).
\end{abstract}

${ }^{10}$ Conforme Lacan: "Se nos é preciso, nesse sentido, ligar-nos a alguma evidência, tomemos então a imagem que se pode dizer erigida no auge da fascinação do desejo, aquela que se renova com a mesma forma do tema platônico no pincel de Botticelli - o nascimento de Vênus, Vênus Afrodite, Vênus saindo das ondas, corpo erigido acima das vagas do amor amargo. Vênus - ou, tanto faz, Lolita. O que nos ensina, a nós, analistas, essa imagem? Soubemos identificá-la bem na equação simbólica, para empregar o termo de Fenichel, Girl = Phallus. [...] Ali onde vemos simbolicamente o falo, é justamente onde ele não está. Ali onde nós o supomos sob o véu, ali onde ele está manifestado na ereção do desejo, é, neste esquema, do lado de cá do espelho. Se ele está ali diante de nós, no corpo fascinante de Vênus, é justamente na medida em que ele não está ali, debaixo. Enquanto essa forma é investida, no sentido em que dissemos há pouco, de todos os atrativos, de todos os Triebregungen que a delimitam por fora, o falo está, com sua carga, do lado de cá do espelho, no interior do recinto narcísico. É por isso que, ali onde ele está, é também ali onde ele não está." (LACAN, 2010, p.471) Então, "poderíamos dizer que a mulher é sem tê-lo. O que pode ser vivido muito penosamente sob a forma do Penisneid [...]" (Ibidem., p.289, grifo meu); e por outro lado, é preciso que o homem "esteja sob o modo do ter, que ele não seja, ele também, sem tê-lo [...]" (Ibidem., p.29o, grifo meu).

"1 “[...] o sujeito masculino que ‘tem' o Falo requer este Outro para confirmar e, assim, ser o Falo em seu sentido 'extensional'.” (BUTLER, 2002, p.56, minha tradução). 
A comunhão heteronormativa entre o ser e o ter parece se atrelar à docilidade feminina e à virilidade masculina, ambas fabricadas e mantidas pelo limite da culpa, sentimento que impede a vivência dos prazeres transgressivos, pois a perda relativa a outras possibilidades de desejo, no caso da melancolia estruturada, é recusada como perda e assimilada como desvio moral. No que tange à matriz heterossexual, as mulheres devem sacrificar a possibilidade de uma constituição distinta de seus desejos e de sua própria subjetividade em razão da objetificação masculina, enquanto os homens devem garantir a manifestação da virilidade, que atesta o seu potencial reprodutivo, pela negação de outras formas de amar. ${ }^{12}$ Nesse sentido, os homens se nutrem das bajulações femininas e as mulheres das interjeições masculinas, de tal modo que a tentativa de amar se torna um ensaio angustiante marcado pelas cláusulas do casamento moderno. Assim, estes que detestam a angústia causada pelo desejo pudico e que astuciosamente desbravam aquilo que poderia ser sentido para além do amor sedimentado na heteronormatividade passam a preocupar o bem-estar da civilização. A melancolia feminina/feminista e a melancolia gay resultariam da recusa do binarismo fálico a partir do qual se estabelece a diferença entre o ser e o ter, isto é, da recusa da elaboração normativa do desejo heterossexual. Do ponto de vista heteronormativo, a melancolia desviante romperia com a decência do Falo e, abandonando sua estrutura, reintegraria a luxúria vivida pelo louco que anunciara a morte de Deus. Logo, os amantes astuciosos teriam se tornado inimigos fálicos ou inimigos públicos que deveriam ser detidos por uma culpa semelhante àquela vivida pelos sujeitos subservientes a Deus. Dessa maneira, a psicanálise parece ter contribuído, em seu limiar patriarcal, para a normalização da melancolia estruturada, a qual é responsável pela arquitetura do desejo heterossexual e, portanto, pela negação da perda da possibilidade de outras formas de amar. Ademais,

\footnotetext{
${ }^{12}$ Parece existir uma relação entre o sacrifício e o canibalismo da comunhão, tal que pensado por Lacan. Não sei elucidar plenamente este vínculo, mas aquela que se sacrifica parece se oferecer ao consumo daquele por quem ela se sacrifica. Talvez seja por meio do sacrifício que "o sujeito vem se situar no cardápio do canibalismo que, todos sabem, nunca está ausente de qualquer fantasia de comunhão. Leiam, a respeito, um tratado daquele autor de que lhes falo ao longo dos anos, numa espécie de retorno periódico, Balthasar Gracián. [...] Trata-se aqui de seu tratado sobre a comunhão, El Comulgatorio, que é um bom texto, no sentido em que nele se revela algo raramente confessado - as delícias do consumo do corpo de Cristo são ali detalhadas, e pedem-nos que nos detenhamos naquela bochecha excelente, naquele braço delicioso, dispenso-o da continuação onde a concupiscência espiritual se prolonga, revelando-nos assim aquilo que permanece sempre implicado nas formas, mesmo as mais elaboradas, da identificação oral." (LACAN, 2010, p.269-270).
} 
ela também teria contribuído para a patologização da melancolia criativa, processo crítico que se atrela à recusa do símbolo fálico. ${ }^{13}$

As considerações de Butler sobre a linguagem patriarcal da psicanálise mostram que o amor é melancólico, a saber, o amor pode conduzir tanto à renúncia de si mesmo como à recusa do Outro. Por um lado, a melancolia amorosa pode levar à mortificação da criatividade crítica de si; por outro lado, a melancolia amorosa também pode desencadear a mortificação do eu que havia sido elaborado sob a demanda do Outro, compreendido aqui como o plano normativo dos códigos e das normas socialmente aceitáveis. A mortificação do eu que introjeta o Outro favoreceria a vitalidade das capacidades criativas do si mesmo, as quais são interditadas por uma sociedade que as concebe como fonte de atos perversos e desviantes. Segundo Butler, a resignação dos sujeitos ao destino prescrito pela heteronormatividade psicanalítica não lhes garante uma recompensa prazerosa, mas os remonta - cito Butler, "à relação torturante entre o Deus do Velho Testamento e aqueles servos humilhados que ofereciam a própria obediência sem recompensa. Tal sexualidade incorpora na atualidade este impulso religioso na forma da demanda por amor." (BUTLER, 2002, p.72, minha tradução) Para Butler, o amor elaborado por essa linguagem estruturada através da lei do patriarcado

\footnotetext{
${ }^{13}$ A partir de Freud, Lacan rapidamente explica, ao final do Livro 8 - A transferência, a diferença e a congruência entre o luto e a melancolia: "Freud insiste muito sobre o que está em questão - o luto consiste em identificar a perda real, peça por peça, pedaço por pedaço, signo por signo, elemento grande I por elemento grande I, até o esgotamento. Quando isso está feito, acaba. Mas o que dizer se esse objeto era um pequeno $a$, um objeto de desejo? O objeto está sempre mascarado por trás de seus atributos, é quase uma banalidade dizer isso. Como é evidente, a coisa só começa a ficar séria a partir do patológico, isto é, da melancolia. O objeto está ali, coisa curiosa, muito menos apreensível por estar certamente presente, e por deslanchar efeitos infinitamente mais catastróficos, já que eles chegam até o esgotamento daquilo a que Freud chama o sentimento mais fundamental, o que os apega à vida. É preciso acompanhar esse texto [Déuil et mélancolie (2011b)] e entender ali o que Freud nos indica de uma certa decepção, que ele não sabe definir, mas está lá. Que traços se deixam ver de um objeto tão velado, mascarado, obscuro? O sujeito não pode investir contra nenhum dos traços daquele objeto que não se vê, mas nós analistas, na medida em que acompanhamos esse sujeito, podemos identificar alguns deles, através daqueles que ele visa como sendo suas próprias características. Nada sou, não sou mais que um lixo. Reparem que não se trata nunca da imagem especular. O melancólico não diz a vocês que ele tem má aparência, ou uma cara feia, ou que é corcunda, mas sim que é o último dos últimos, que acarreta catástrofes para toda a sua parentela etc. Em suas autoacusações ele está inteiramente no domínio do simbólico. Acrescentem aí o ter: ele está arruinado. [...] Só farei indicar hoje a vocês, designando-lhe um ponto específico que é no meu entender, ao menos por ora, um ponto de concorrência entre o luto e a melancolia. Trata-se do que vou chamar, não de luto, nem de depressão por conta da perda de um objeto, mas um remorso de um certo tipo, desencadeado por um desenlace que é da ordem do suicídio do objeto. Um remorso, portanto, a propósito de um objeto que entrou, de algum modo, no campo do desejo e que, por sua ação, ou por qualquer risco que correu na aventura, desapareceu." (LACAN, 2010, pp.480-481).
} 
retoma alguns elementos dos flagelos religiosos, pois reitera a obediência, o sacrifício e o sofrimento de todos os indivíduos que, permanecendo incondicionalmente fiéis ao Falo, jamais atingem a perfeição heterossexual, a qual continua, entretanto, a funcionar como um horizonte transcendental de normalidade a ser constantemente reiterado e vigiado.

A partir disso, talvez seja possível afirmar que a obediência ao Falo visa compensar as frustrações e os enfados dos amores modernos pela promessa da salubridade mental e física. Logo, o drama do amor moderno começaria pelo sacrifício da criatividade crítica de si mesmo: a dimensão criativa do si mesmo é aniquilada (ou se aniquila) na expectativa de que o Falo, afirmado como o paradigma normativo atual, seja incorporado como a consciência do eu. Em outras palavras, o si mesmo renuncia à possibilidade de uma experiência afetiva criativa em virtude da internalização do modelo heteronormativo que vigora na sociedade. Por medo da insalubridade e de represálias médico-jurídicas, o si mesmo renuncia à sua criatividade e repete os costumes que vigem na cultura legitimada pela racionalidade fálica.

Como mostra Butler, os recursos metafóricos da psicanálise nos remetem às simbologias religiosas. Todavia, a renúncia cristã concernente à constituição criativa de si mesmo parece se distinguir da renúncia psicanalítico-patriarcal, visto que esta não conduz à elaboração de um amor universal fundado na supervalorização moral da alma em relação ao corpo. Para Butler, o Falo corresponde ao símbolo que enseja a modelação do corpo e a orientação do desejo, ao passo que Deus, segundo Foucault, consistiria no símbolo por meio do qual o corpo é purificado e os desejos são expurgados. Mais precisamente, para Foucault a purificação cristã do corpo se estabelece através da diferenciação entre - eu o cito - "os movimentos da alma e aqueles que se seguem da libido." (FOUCAULT, 2001, no 295, p.995, minha tradução) No cristianismo a renúncia de si tem como finalidade a elaboração de uma consciência agraciada capaz de experenciar o amor divino. Sendo assim, a renúncia da constituição autárquica de si mesmo visa a essencialidade da identificação entre a razão humana e a razão divina, processo responsável pelo exercício de autoridade da alma sobre o corpo. Isso significa que para o cristianismo o desejo é purificado quando a libido é subsumida à procriação e quando a verdade da vontade é desvelada como o amor incondicional por Deus. A 
renúncia às luxúrias da carne se sucede em virtude da decifração da natureza da vontade humana - cito Foucault: "quanto mais descobrimos a verdade sobre nós mesmos, mais nós devemos renunciar a nós mesmos." (Ibidem, p.991, minha tradução) Dito de outro modo, os desejos são acrisolados para que a verdade da vontade se manifeste e prevaleça sobre as tentações demoníacas. A consciência do eu se institui por meio da introjeção do olhar divino e o amor passa a ser vivenciado como uma experiência universal, ou seja, o amor por si mesmo e pelos outros passa a ser concebido como o amor absoluto pelo Ideal divino e por seus valores eternos.

Diferentemente, a renúncia psicanalítica da criatividade do si mesmo não acontece em razão da supervalorização moral da alma e da naturalização do amor universal, mas sim em virtude da normalização do amor heterossexual e da padronização do feminino e do masculino. O amor heterossexual deixa de ser uma manifestação da graça divina e passa a ser uma realidade imanente justificada por uma entidade que se articula à consciência através das figurações sociais da mãe e do pai, as quais, ao invés de habitarem o reino dos fins, participam da população e do Estado que a rege. A linguagem patriarcal da psicanálise ratifica e retifica Deus quando o retoma sob a forma do Falo, o qual passa a operar como um fundamento psíquico e social que estrutura a harmonia entre as demandas jurídicas da esfera pública e a salubridade da vida privada ou da intimidade erótico-conjugal. Por isso, a culpa atrelada à submissão ao Falo operaria da mesma forma que a culpa relativa à subserviência a Deus. Nestes casos, o sentimento de culpa parece se configurar como um instrumento de controle que, desde o interior do sujeito, age de modo a inibir a liberdade estética do desejo e do amor que dele se segue.

\section{Uma breve conclusão: sobre nossa ambivalência}

Precisamos, com efeito, nos livrar desta culpa fálico-cristã, mas nem tudo é tão simples assim, pois como explica Butler, em nosso eu, o humor melancólico varia: ora ele é proeminentemente oblativo, ora proeminentemente criativo. Esta vacilação provoca e é provocada pelos diferentes aspectos que nos atravessam e que nos constituem. Então, para que possamos nos livrar deste tipo de culpa e, assim, nos 
desidentificarmos do autoritarismo e da tirania do Falo que insiste em nos censurar desde o interior de nós mesmas, precisamos - cito Butler: “[...] encontrar um modo de viver e de agir com a ambivalência - um modo no qual a ambivalência seja entendida não como um impasse, mas como uma partilha interna que clama por uma orientação ética e prática." (BUTLER, 2020, p.172, minha tradução)

Quando afirmamos a ambivalência que nos constitui e que se atrela aos processos de identificação e des-identificação do si em relação ao Outro, somos capazes de dar ensejo ao exercício crítico da reflexividade, o qual coloca em questão a culpa fálico-cristã. Nesse sentido, parece-me que, de acordo com Butler, é justamente a reflexividade crítica que dá uma orientação ética e prática para a ambivalência melancólica que nos atravessa.

Hoje, não abordarei a relação entre melancolia, crítica e ambivalência, pois este ainda é um assunto novo para mim, o qual pretendo desenvolver no decorrer de minhas pesquisas pós-doutorais. Mas, seja como for, por hora, o que podemos perceber é que a melancolia é um conceito chave para Butler, conceito que nos permite compreender os jogos entre o governo de si e o governo dos outros tanto no que tange à esfera social do poder, quanto no que se refere à sua vida psíquica. Por meio da melancolia, Butler nos mostra que nossa intimidade é mais frágil do que imaginávamos, já que nossa topografia interna está imbricada à esfera social que a circunda; contudo, por meio da melancolia, Butler também nos mostra que nossa intimidade é mais potente do que poderíamos conceber, pois a revolta muitas vezes irrompe de dentro de nós mesmas, emerge como um surto melancolicamente criativo, ou maníaco, que pergunta: como amar, como amar diferentemente, não deste modo, não por isto, não por eles?

Muito obrigada! $!^{14}$

\section{Referências}

BUTLER, J. Gender Trouble: feminism and subversion of identity. London: Taylor \&

\footnotetext{
${ }^{14}$ Agradeço imensamente a Comissão Executiva da Revista Sociologias Plurais pela cuidadosa transcrição de minha fala.
} 
Francis e-Library, 2002.

BUTLER, J. Giving an Account of Oneself. New York: Fordham University Press, 2005.

BUTLER, J. "Can one lead a good life in a bad life?". Radical Philosophy, 2012. Disponível em: <https://www.radicalphilosophy.com/article/can-one-lead-a-good-lifein-a-bad-life>. Acesso em: março de 2018.

BUTLER, J. "What is Critique? An Essay on Foucault's Virtue". Transversal, 2001. Disponível em: <https://eipcp.net/transversal/o8o6/butler/en.html>. Acesso em: 26 de Janeiro de 2017.

BUTLER, J. The force of non-violence. New York: Verso Books, 2020.

BUTLER, J. The psychic life of power: theories in subjection. California: Stanford University Press, 1997.

FOUCAULT, M. «À propos de la généalogie de l'éthique: un aperçu du travail en cours». In: . Dits et Écrits II. 1976-1988. Paris: Gallimard, 2001, no 326, pp. 1202-1230.

FOUCAULT, M. Qu'est-ce que la critique; La culture de soi. Paris: Vrin, 2015b.

FOUCAULT, M. «Qu'est-ce que les Lumières?». In: Dits et Écrits II. 1976-1988. Paris: Gallimard, 2001, no 339, pp.1381-1397.

FOUCAULT, M. «Sexualité et solitude». In: Dits et Écrits II. 1976-1988. Paris: Gallimard, 2001, no 295, pp.987-997.

FREUD, S. “A cabeça de Medusa”. Clínica \& Cultura, tradução de Ernani Chaves, Sergipe, vol.2, 2013, pp.91-93.

FREUD, S. “A feminilidade”. In: Obras completas volume 18 (1930-1936). Tradução de Paulo César de Souza. São Paulo: Companhia das Letras, 2010.

FREUD, S. “A organização genital infantil”. In: Obras completas volume 16 (1923-1925). Tradução de Paulo César de Souza. São Paulo: Companhia das Letras, 2011 . FREUD, S. Deuil et mélancolie. Trad: Aline Weill. Paris: Payot \& Rivages, 2o11b.

FREUD, S. “O Eu e o ID”. In: Obras completas volume 16 (1923-1925). Tradução de Paulo César de Souza. São Paulo: Companhia das Letras, 2011c.

FREUD, S. O mal-estar na civilização. Tradução de Paulo César de Souza. São Paulo: Companhia das Letras, 2011c.

FREUD, S. Pour introduire le narcissisme. Trad: Olivier Mannoni. Paris: Payot \& 
Rivages, 2012.

LACAN, J. “A significação do falo”. In: Escritos. Rio de Janeiro: Jorge Zahar, 1998.

LACAN, J. O Seminário, Livro 8: A Transferência. Tradução de Dulce Duque Estrada. Rio de Janeiro: Zahar, 2010.

NIETZSCHE, F. A Gaia e a Ciência. Tradução de Paulo César de Souza. São Paulo: Companhia das Letras, 2012. 